\title{
Comparison of Engineering Skills with IR 4.0 Skills
}

\author{
https://doi.org/10.3991/ijoe.v15i10.10879 \\ F. Mohd Kamaruzaman( ${ }^{\bowtie}$, R. Hamid, A.A. Mutalib, M.S. Rasul \\ Universiti Kebangsaan Malaysia, Selangor D.E., Malaysia \\ fathiyah@ukm.edu.my
}

\begin{abstract}
In the heart of Industrial Revolution 4.0 (IR 4.0) is a set of rapidly evolving and converging technologies, which can bring sizeable consequences toward the economy, lifestyle, health, education, labour markets and skills development. The changes in the workforce setting of IR 4.0 have driven the need to obtain new skills that are aligned with the advancement of modern technology. This situation manifested itself since the current skills are no longer relevant and about to face a significant change in the entire field of work. Skills that are taught to the future graduates are out of sync with the current need of the industry, which eventually cost them their chance to fulfil the need of the workforce and increase the rate of unemployment among graduates. As a preparation to take up the challenges of the IR 4.0, graduates need to be exposed to appropriate skills to ensure their employment and to remain functioning in the ever-changing industry and technology environment. In this regard, this paper was done to compare the existing engineering skills with the new skills necessary for the IR 4.0. This article adopted a systematic review method considering previous studies on engineering skills required by the engineering accreditation bodies. Results from this study revealed seven skills identified as the gap in both sets of skills. These skills include analytical thinking and innovation; active learning and learning strategies; creativity, originality and initiative; technology design and programming; critical thinking and analysis; emotional intelligence; and system analysis and evaluation. Findings of this study can be used as a guidance to understand the current skills needed so that engineering graduates will have no problem in getting a job in the future.
\end{abstract}

Keywords-Skills Development, Industrial Revolution 4.0, Engineering Graduates

\section{$1 \quad$ Introduction}

The fourth industrial revolution (IR 4.0) is a part of the digital transformation. It is characterised by the fusion and amplification of emerging technology breakthroughs in artificial intelligence, automation and robotics, multiplied by the far-reaching connectivity between billions of people with mobile devices with unprecedented access to data and knowledge [1-3]. [2] added that the beginning of a revolution is going to fundamentally change the way humans live, work and relate to one another. 
Historically, the first industrial revolution was triggered by the construction of railroads to the invention of steam engine ushered in mechanical production [4]. Meanwhile in the second industrial revolution, mass production began to accelerate, fostered by the advent of electricity and assembly line. The third industrial revolution was called a computer or digital revolution because of the development of semiconductors, mainframe computing, personal computing and the internet. However, the fourth industrial revolution is beyond smart as well as connected machines and systems. [4] explained that the fusion of new technologies and their interaction across the physical, digital and biological domains makes the IR 4.0 fundamentally different from the previous revolutions. These new technologies can bring sizeable consequences toward the economy, lifestyle, health, education, labour markets and skills development.

\subsection{Impact of IR 4.0 on job placement and skills development}

As mentioned above, the employment scenario in the industry is influenced by the rapid development of technology in the IR 4.0. This scenario is due to the advancement of technologies that will replace the human workforce with automation and robotic. Table 1 illustrates the expected impact of automation on the field of work reported by previous studies.

Table 1. Expected effects of automation on field of work

\begin{tabular}{|l|l|}
\hline \multicolumn{1}{|c|}{ Organisation } & \multicolumn{1}{c|}{ Expectation } \\
\hline University of Oxford & $47 \%$ of works in America at high risk of jobs replaced by automation \\
\hline $\begin{array}{l}\text { Pricewaterhouse } \\
\text { Coopers }\end{array}$ & $\begin{array}{l}38 \% \text { 38\% of jobs in America, 30\% of jobs in UK, 21\% in Japan and 35\% in } \\
\text { Germany at risk to automation }\end{array}$ \\
\hline ILO & ASEAN-5: $56 \%$ of jobs at risk to automation in next 20 years \\
\hline OECD & $\begin{array}{l}\text { OECD average: } 9 \% \text { of jobs at high risk. Low risk of complete automation but an } \\
\text { important share (between } 50 \%-70 \% \text { ) of automatable tasks at risk }\end{array}$ \\
\hline Bruegel & EU countries: between $47 \%$ and $54 \%$ of jobs are risk of automation \\
\hline Roland Berger & $\begin{array}{l}\text { Western Europe: } 8.3 \mathrm{~m} \text { jobs lost in industry against } 10 \mathrm{~m} \text { new jobs created in } \\
\text { services by } 2035 .\end{array}$ \\
\hline World Bank & $2 / 3$ of all jobs in developing countries are susceptible to automation. \\
\hline McKinsey & $60 \%$ of all occupations have at least 30\% technically automatable activities \\
\hline
\end{tabular}

Source : [5]

The modernisation of the current technology has resulted in many new forms of job introduced in all areas of work, causing the current work practice to be no longer suitable to meet market demands [6]. This is supported by some recent studies stating that technological changes can lead to a huge amount of job destruction [7-9]. In addition, the study by [10] estimated that $35 \%$ jobs may disappear due to new technologies in the next two decades. Besides, the [11] calculated that there will be $66.6 \%$ of job susceptible to be made redundant in the developing world due to technology disruption.

A survey has been conducted by the [1] involving nine industries (basic \& infrastructure, consumer, energy, financial services \& investors, healthcare, information 
and communication technology, media, entertainment \& information, mobility, professional services) in 2015. The findings demonstrated significant changes in job demand or job offer from 2015-2020. Table 3 shows a clear difference in job requirement for the IR 4.0.

Table 2. Work sector demand from 2015-2020

\begin{tabular}{|c|l|c|l|}
\hline Demand & \multicolumn{1}{|c|}{ Field of work/sector } & Demand & \multicolumn{1}{|c|}{ Field of work/sector } \\
\hline$-4,759$ & Office and administration & +492 & Business and Financial Operations \\
\hline-1609 & Manufacturing and Production & +416 & Management \\
\hline-497 & Construction and Extraction & +405 & Computer and Mathematical \\
\hline-151 & $\begin{array}{l}\text { Arts, Design, Entertainment, Sports } \\
\text { and Media }\end{array}$ & +339 & Architecture and Engineering \\
\hline-109 & Legal & +303 & Sales and Related \\
\hline-40 & Installation and Maintenance & +66 & Education and Training \\
\hline
\end{tabular}

Based on this table, there was a significant drop in employment opportunities in office and administration work, manufacturing \& production, construction $\&$ extraction, arts, legal as well as installation \& machines. Accordingly, reduced job offers were also expected in "Office and Administrative" job family, followed by service and sales occupations due to such change drivers such as mobile internet, cloud technology and workplace flexibility $[1,7]$. For example, book storage function in libraries is replaced by a computing system that makes it easier for users to search and retrieve books. Nevertheless, the IR 4.0 phenomenon is capable of opening various job opportunities as well as new industries either in the physical domain (intelligent robots, autonomous drones, driverless cars, 3D printing and smart sensor), digital (the use of IoT, data highway) or biological (individual genetic make-up and bio-printing).

In line with this, the study conducted by the [12] presented that the potential for job creation outweighed the loss of jobs due to automation and technologies innovation. Some examples included what had happened in France over the past 15 years where the extensive Internet usage has resulted in the abolishment of 0.5 million jobs. Nonetheless, at the same time, it has opened 1.2 million new job opportunities. Meanwhile, in the context of the US, new technologies are able to create an increase of 4.9 job opportunities in the civil service [5]. In addition, advancement in 3D printing technology might reduce the amount of labour needed in production, but these negative employment effects are likely to be outweighed by the birth of a new industry supplying printing materials [13]. A report by the [14] also confirmed that even if robotics start to displace large numbers of workers, jobs dependent on human traits including creativity and emotional intelligence may become numerous. In short, the development of sophisticated technology has changed the practice and setting of jobs in all sectors, which indirectly reduced and offered jobs significantly. This situation spans old and new jobs including mastering and developing skills.

Changes in the field of work in the IR 4.0 setting have further increased the gaps in skills mismatch [15, 16], which then led to the need of acquiring new skills [17]. Based from The Future of Jobs Report, by 2020, more than one-third of the core skills required in most occupations would include skills that have not been considered important in today's work [1]. It was also emphasised that countries in Asia Pacific will 
face a unique challenge of increasing job opportunities, but lack the workers with skills required to fill vacancies for new and old posts.

According to [18], out of all professional vacancies in the fields of science, research, engineering and technology, $43 \%$ of them were challenging to fill due to skills shortage. Additionally, a survey study by [19] revealed that the absence of skilful workers was the biggest concern of the manufacturers. Besides, a study by [20] on graduates from UUM and USM discovered that only $35.6 \%$ of the students acknowledged that they know the forms and types of skill required by the employers. Whereas $18.9 \%$ of the students did not know them and the majority of students $(45.5 \%)$ were unsure of the skills required by the employers. This suggests that the future world employment scenario will not be about reduced job offers, but the lack of skills mastery in line with the current needs and demands.

If seen from this perspective, although the future work world will be dominated and overwhelmed by automation, human skills and intelligence still play an important role in developing the economy of a country. The advancement of technology in the IR 4.0 calls for today's engineering graduates to work and compete in a work atmosphere full of automation, virtual and borderless world. Accordingly, engineering graduates need to be prepared for jobs that never exist for the last 10 or five years. As a preparation to take up the IR 4.0 challenges, there is a growing demand for engineering graduates to master certain skills to be able to secure their career. Students who put their effort to learn new things and acquire certain skills not only make them confident and self-assured, but also give them an advantage when attending job interviews $[\underline{21}, \underline{22}]$.

It is important for engineering graduates to master the skills required in the IR 4.0 because engineering knowledge alone is no longer sustainable. Hence, this paper systematically reviews the existing skills set and compare them with the new skills required for IR 4.0 graduates to identify the gap in both sets. The findings from this study would be beneficial for all the parties (industries, institutions and graduates) to ensure that newly graduates will survive the IR 4.0 setting.

\section{Methodology}

In conducting this study, a systematic review was used as the its methodology. According to [23], a systematic review methodology is applied to track, evaluate and synthesise the best studies on issues related to research problems by providing evidence and informative answers. A study could be conducted inclusively if the researcher cautiously read the document by gathering and analysing information from various sources [24]. Previous researchers have utilised systematic review methodology in their studies such as [25] in exploring high income community education in Malaysia; [26] in identifying students' career choice in Malaysian skill certification system; [27] in identifying elements, influences and entrepreneurial learning processes for vocational colleges in Malaysia; and [28] in identifying organisational factors affecting industry involvement for the National Dual Training System program. 
Particularly, the systematic review methodology follows the guidelines proposed by [29]. There are five procedures to conduct systematic literature review (SLR) as follow:

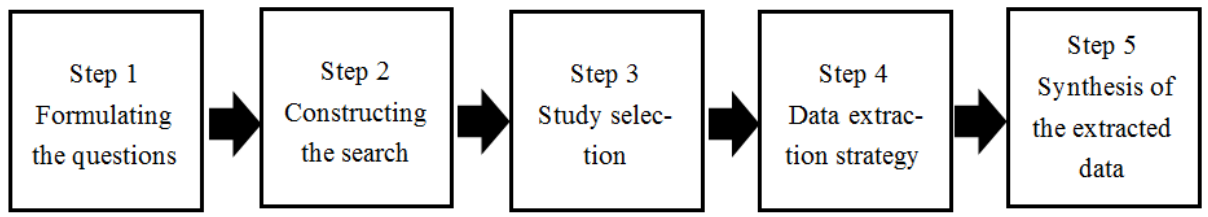

Fig. 1. Procedures to conduct SLR

\subsection{Formulating the questions}

The aim of this study is to answer the following objectives:

1. To enhance the understanding on the skills set by engineering accreditation bodies as per Washington Accord.

2. To investigate the skills necessary for IR 4.0 graduates.

3. To compare the skills of engineering graduates with the skills necessary for IR 4.0.

\subsection{Constructing the search}

Accordingly, research papers were obtained from five journals and articles databases namely ProQuest, Science Direct, Wiley, Taylor \& Francis and IEEE. These following databases were chosen as the researchers get a free access under Universiti Kebangsaan Malaysia. Related information was obtained from various government agencies' reports, journals, books, newspapers and electronic references from relevant websites. Three keywords were used in the information search, which are the industrial revolution 4.0, non-technical skills and engineering graduate.

\subsection{Study selection}

In order to get the relevant and best articles to review, the following criteria were used to search these sources and select the papers:

1. Duplicated papers were removed and relevant studies were selected by judging titles.

2. One of the keyword search terms was employed to search for the titles and abstracts of the articles.

3. The studies had results or findings. 


\subsection{Data extraction strategy}

According to $[\underline{29}, \underline{30}]$, this step is necessary to design data extraction forms for accurately recording the information obtained from the primary studies. Information extraction involves drawing up a nitty gritty table depicting each investigation checked in detailed. In other words, this step is a filtering process where only articles that meet the specified criteria are selected. Typically, the number of these selected articles are less than the original taken from the journal database.

\subsection{Synthesis of the extracted data}

In reporting the data synthesis, this study classified the findings of data to certain sections including the distribution by year of publication, journal, type, subject area and research approaches.

\section{$3 \quad$ Findings}

In this study, two major aspects were discussed in relation to the development of skills for engineering graduates. Those aspects were the skills set by engineering accreditation bodies as per Washington Accord and those necessary for IR 4.0 graduates. These two aspects are important as a major reference for the findings of this study, which compare the existing skills with the skills needed in IR 4.0 especially in engineering.

The focus of this study was limited to non-technical skills that must be mastered by engineering graduates. Justification on the focus of this study is that most employers prefer the engineering graduates who possess excellent professional skills or nontechnical skills as well as good academic qualifications [31-40].

\subsection{Engineering skills set}

This section discusses the skills set by engineering bodies as per Washington Accord. Twenty countries have signed the Washington Accord since 1989 until today. Each country is represented by a specific accreditation body responsible for determining the engineering attributes of its students so that they can perform their duties efficiently. Setting up engineering attributes portrays that these countries are concerned with generic skills mastery for the benefit of self and national development.

In this study, the engineering skills framework set by countries was identified through literature review and previous studies [22, 41-47]. Table 4 below displays the list of skills required by engineering accreditation bodies for 18 countries under the Washington Accord. 
Table 3. Engineering skills set by 18 countries

\begin{tabular}{|c|c|}
\hline Country & Non-technical skills \\
\hline A. Malaysia & $\begin{array}{l}\text { Problem analysis; technology; ethical principles; communication; teamwork; lifelong } \\
\text { learning }\end{array}$ \\
\hline B. United States & Communication; teamwork; lifelong learning; professionalism; problem solving \\
\hline C. Singapore & $\begin{array}{l}\text { Communication; global mindset; lifelong learning; problem solving and decision } \\
\text { making; professionalism; information and communication technology; management }\end{array}$ \\
\hline D. Australia & Communication; teamwork; learning; professional and ethics responsibility \\
\hline E. Ireland & Problem solving; ethical standards; team spirit; lifelong learning; communication \\
\hline F. United Kingdom & $\begin{array}{l}\text { Problem solving; oral and written communication; team roles and work as a member; } \\
\text { lifelong learning; professional expertise }\end{array}$ \\
\hline G. Korea & $\begin{array}{l}\text { Information technology; project team; communication; ethics; lifelong learning; } \\
\text { problem solving }\end{array}$ \\
\hline H. Hong Kong & $\begin{array}{l}\text { Teamwork; problem solving; professional and ethics responsibility; communication; } \\
\text { lifelong learning; computer and IT skill }\end{array}$ \\
\hline I. Japan & Thinking skill; technology; oral and written communication; lifelong; work in a team \\
\hline J. Sri Lanka & Problem analysis; ethics; teamwork; communication; management; lifelong learning \\
\hline K. Canada & $\begin{array}{l}\text { Problem solving; member and leader in team; communication; professionalism; } \\
\text { management; learn continuously }\end{array}$ \\
\hline L. India & $\begin{array}{l}\text { Solve engineering problem; professional and ethical responsibilities; verbal and } \\
\text { written communication; teamwork; self-education }\end{array}$ \\
\hline M. New Zealand & $\begin{array}{l}\text { Problem analysis; ethics; role in and diversity of team; communication; management; } \\
\text { continuing learning }\end{array}$ \\
\hline N. South Africa & $\begin{array}{l}\text { Problem solving; information technology; written and oral communication; team- } \\
\text { work; independent learning; professionalism; management }\end{array}$ \\
\hline O. Chinese Taipei & Management; communication; work in team; ethics; problem solving \\
\hline P. Turkey & $\begin{array}{l}\text { Problem solving; information technology; teamwork; Turkish proficiency; presenta- } \\
\text { tion skills; lifelong learning; ethical principles; management }\end{array}$ \\
\hline Q. Russia & $\begin{array}{l}\text { Problem analysis; ethics; communication; leader or member in diverse team; lifelong } \\
\text { learning; management }\end{array}$ \\
\hline R. Pakistan & $\begin{array}{l}\text { Problem solving; ethics; leader or member in team; communication; management; } \\
\text { lifelong learning }\end{array}$ \\
\hline
\end{tabular}

Based on the above list (Table 4), communication skill was the most emphasised by all the 18 countries. Meanwhile, two skills agreed by at least 17 countries were teamwork and lifelong learning skills. Problem solving skills and ethics were chosen by at least 16 countries. Meanwhile, management skills were chosen by at least nine countries. Decision making skills and thinking skills were the least emphasised skills for engineering graduates by these countries. Thus, it shows that every country had chosen similar criteria to other countries. Additionally, the ranking of 10 preferred skills derived by this table were:

1. Communication skill

2. Teamwork

3. Lifelong learning

4. Problem solving skill

5. Ethics and professionalism

6. Management

7. Technology skill

8. Decision making 


\section{Thinking skill}

10. leadership skills

Yet, the engineering graduates' skills set studied by previous researchers was no longer appropriate to the needs of the industry and needs improvements in line with the challenges of the Industrial Revolution 4.0.

\subsection{IR 4.0 Skills}

In this decade, the whole nation has begun to feel and face the beginning of the Industrial Revolution 4.0. As a preparation, efforts to upgrade skills (upskilling) and master new skills (reskilling) are the main agenda of all parties such as HEIs, vocational institutions, governments and industries. Similar to the previous industrial revolution scenarios (IR 1.0, IR 2.0, IR 3.0), skills development issues by various institutions took a while to resolve as per current situation. This situation is no exception in IR 4.0. However, the situation becomes more difficult due to the rapid development of new technologies. This issue has been further explained by [1] on the key skills highlighted for graduates following the development in the Industrial Revolution 4.0. Table 5 shows the top 10 skills needed in IR 4.0.

Table 4. 10 top skills needed in IR 4.0

\begin{tabular}{|c|l|c|l|}
\hline \multicolumn{2}{|c|}{$\mathbf{2 0 1 5}$} & \multicolumn{2}{|c|}{$\mathbf{2 0 2 0}$} \\
\hline 1 & Complex Problem Solving & 1 & Complex Problem Solving \\
\hline 2 & Coordinating with Others & 2 & Critical Thinking \\
\hline 3 & People Management & 3 & Creativity \\
\hline 4 & Critical Thinking & 4 & People Management \\
\hline 5 & Negotiation & 5 & Coordinating with Others \\
\hline 6 & Quality Control & 6 & Emotional Intelligence \\
\hline 7 & Service Orientation & 7 & Judgement and Decision Making \\
\hline 8 & Judgement and Decision Making & 8 & Service Orientation \\
\hline 9 & Active Listening & 9 & Negotiation \\
\hline 10 & Creativity & 10 & Cognitive Flexibility \\
\hline
\end{tabular}

The difference between skills in 2015 and 2020 is shown in this table. It was due to a bigger focus on artificial intelligence and automation in the 4th Industrial Revolution. In line with this, graduates should be given an early exposure to the need for mastering the new skills as mentioned in the above table. Furthermore, the same needs and understanding between HEIs and employers on the new set of skills that should be mastered by graduates are very important for them to take up the challenges of IR 4.0.

Currently, [48] has come out with a latest report following the report published in 2016. In the current report, majority of employers expected that most of the current skills will not be relevant by the year 2022 and will witness a huge difference in every field of work. Table 6 depicts the comparison in skills demand from the year 20182022. 
Table 5. Skills demand in 2018 vs 2022

\begin{tabular}{|c|l|c|l|}
\hline \multicolumn{2}{|c|}{2018} & \multicolumn{2}{|c|}{2022} \\
\hline 1 & Analytical thinking and innovation & 1 & Analytical thinking and innovation \\
\hline 2 & Complex problem solving & 2 & Active learning and learning strategies \\
\hline 3 & Critical thinking and analysis & 3 & Creativity, originality and initiative \\
\hline 4 & Active learning and learning strategies & 4 & Technology design and programming \\
\hline 5 & Creativity, originality and initiative & 5 & Critical thinking and analysis \\
\hline 6 & Attention to detail, trustworthiness & 6 & Complex problem solving \\
\hline 7 & Emotional Intelligence & 7 & Leadership and social influence \\
\hline 8 & Reasoning, problem solving and ideation & 8 & Emotional Intelligence \\
\hline 9 & Leadership and social influence & 9 & Reasoning, problem solving and ideation \\
\hline 10 & Coordination and time management & 10 & System analysis and evaluation \\
\hline
\end{tabular}

Based on tables 5 and 6 , there was a significant difference observed regarding the need for the mastery of skills in the IR 4.0. [1] expected a change in skills within 5 years, which is from the year 2015-2020. It was apparent that there were several previous skills that became necessary for the graduates, which were not important before. These include complex problem solving, emotional intelligence, negotiation and cognitive flexibility skills. Nonetheless, a current report by [48] demonstrated the need in mastering the skills in the IR 4.0 from the year 2018-2022. The differences in both comparisons from the year 2015-2020 with 2018-2022 were analytical thinking and innovation, active learning and learning strategies, technology design and programming, leadership and social influence, reasoning, problem solving and ideation, as well as system analysis and evaluation.

In this regard, graduates should be given early exposure to the existence of the need to master new skills as required in the above table so that their skills will always be relevant to IR 4.0 challenges. Additionally, responsible parties in the development of skills such as HEIs and employers should have the same understanding and needs so that the skills applied to graduates can help them to work in the IR 4.0 settings.

\subsection{Comparison of existing skills and IR 4.0 skills}

IR 4.0 challenges require a new skills set to be mastered by each graduate or employee. Nowadays, efforts to identify and forecast new skills become the main concern of the governments, businesses and individuals. Generally, many studies have been previously conducted by researchers on skills for graduates in various fields. Trend changes in the phrases used often referred to graduate attributes, soft skills, essential skills, non-technical skills, generic skills, basic skills, marketable skills, key skills, work skills, transferable skills or even professional skills.

The skills set referred to depends on a certain type of works and current changes in the job market. However, previous studies in engineering focused only on the following set of skills namely communication skills, problem solving skills and decision making, teamwork skills, lifelong learning and professionalism [22, 43, 45, 46, 4962]. However, the engineering graduates' skills set studied by previous researchers was no longer appropriate to the needs of the industry and needs improvements in line 
with the challenges of the Industrial Revolution 4.0. Table 7 illustrates the comparison between the existing skills (Table 5) and IR 4.0 skills (Table 6).

Table 6. Comparison of engineering skills with IR 4.0 skills

\begin{tabular}{|c|c|c|c|c|c|c|c|c|c|c|c|c|c|c|c|c|c|c|}
\hline \multirow{2}{*}{\begin{tabular}{|l|}
\multicolumn{1}{|c|}{ WEF (2018) } \\
Analytical thinking and \\
innovation
\end{tabular}} & $\mathbf{A}$ & B & $\mathbf{C}$ & D & $\mathbf{E}$ & $\mathbf{F}$ & $\mathbf{G}$ & $\mathbf{H}$ & I & $\mathbf{J}$ & $\mathbf{K}$ & $\mathbf{L}$ & $\mathbf{M}$ & $\mathbf{N}$ & $\mathbf{O}$ & $\mathbf{P}$ & $\mathbf{Q}$ & $\mathbf{R}$ \\
\hline & & & & & & & & & & & & & & & & & & \\
\hline \multicolumn{19}{|l|}{$\begin{array}{l}\text { Active learning and learning } \\
\text { strategies }\end{array}$} \\
\hline \multicolumn{19}{|l|}{$\begin{array}{l}\text { Creativity, originality and } \\
\text { initiative }\end{array}$} \\
\hline \multicolumn{19}{|l|}{$\begin{array}{l}\text { Technology design and } \\
\text { programming }\end{array}$} \\
\hline \multicolumn{19}{|l|}{ Critical thinking and analysis } \\
\hline Complex problem solving & $\sqrt{ }$ & $\sqrt{ }$ & $\sqrt{ }$ & & $\sqrt{ }$ & $\sqrt{ }$ & $\sqrt{ }$ & $\sqrt{ }$ & & $\sqrt{ }$ & $\sqrt{ }$ & $\sqrt{ }$ & $\sqrt{ }$ & $\sqrt{ }$ & $\sqrt{ }$ & $\sqrt{ }$ & $\sqrt{ }$ & $\sqrt{ }$ \\
\hline $\begin{array}{l}\text { Leadership and social influ- } \\
\text { ence }\end{array}$ & & & & & & & $\sqrt{ }$ & & & & $\sqrt{ }$ & & $\sqrt{ }$ & & & & $\sqrt{ }$ & $\sqrt{ }$ \\
\hline \multicolumn{19}{|l|}{ Emotional intelligence } \\
\hline $\begin{array}{l}\text { Reasoning, problem solving } \\
\text { and ideation }\end{array}$ & $\sqrt{ }$ & $\sqrt{ }$ & $\sqrt{ }$ & & $\sqrt{ }$ & $\sqrt{ }$ & $\sqrt{ }$ & $\sqrt{ }$ & & $\sqrt{ }$ & $\sqrt{ }$ & $\sqrt{ }$ & $\sqrt{ }$ & $\sqrt{ }$ & $\sqrt{ }$ & $\sqrt{ }$ & $\sqrt{ }$ & $\sqrt{ }$ \\
\hline $\begin{array}{l}\text { System analysis and evalua- } \\
\text { tion }\end{array}$ & & & & & & & & & & & & & & & & & & \\
\hline
\end{tabular}

Table 7 shows the comparison between the skills set by engineering accreditation bodies and new skills highlighted by [48]. From this list, seven skills showed a significant gap between existing skills and IR 4.0 skills namely analytical thinking and innovation; active learning and learning strategies; creativity, originality and initiative; technology design and programming; critical thinking and analysis; emotional intelligence; and system analysis and evaluation. Some of these seven skills have not been explored regarding their definitions and attributes specifically in engineering field compared to other skills studied by previous researchers namely complex problem solving; leadership and social influence; and reasoning, problem solving and ideation.

\section{Conclusion}

Understandably, skills development and mastery are the most important elements to ensure that graduates are competitive in pursuing their career. In this paper, two aspects have been discussed regarding the development of skills particularly for engineering students. The first aspect has reviewed the existing engineering skills from 18 country members of the Washington Accord (Malaysia, the Unites States of America, Singapore, Australia, Ireland, United Kingdom, Korea, Hong Kong, Japan, Sri Lanka, Canada, India, New Zealand, South Africa, Chinese Taipei, Turkey, Russia and Pakistan). Based on the mapping made, the skill mostly emphasised by all countries was communication skills. Accordingly, the second aspect discussed was on the existence of demand for new skills in the IR 4.0. In the setting of IR 4.0, graduates should be given early exposure regarding the demand in skills that are previously unimportant. 
This is crucial so that every graduate produced by the HEIs is always in the forefront and aware of the current needs of the industry. At the same time, it can propagate the skills gap and unemployment issues among engineering graduates.

Subsequently, the findings from the mapping of engineering skills have been used to highlight the skills gap between existing skills and IR 4.0 skills. There were seven skills namely analytical thinking and innovation, active learning and learning strategies, creativity, originality and initiative, technology design and programming, critical thinking and analysis, emotional intelligence, as well as system analysis and evaluation that have not been studied by previous studies compared to the three other skills. Findings from this study will be used in further study to develop an IR 4.0 skills framework equipped with clear attributes for each skill. This framework can be used as a guidance by HEIs and the industry for ensuring that engineering graduates are competitive and have no problem in getting a job in the future.

\section{Acknowledgement}

The authors would like to thank the financial support of Universiti Kebangsaan Malaysia through grant AP-2015-015.

\section{References}

[1] World Economic Forum. The future of jobs : Employment, skills and workforce strategy for the fourth Industrial Revolution. Geneva; 2016.

[2] Klaus S. The Fourth Industrial Revolution. Switzerland: World Economic Forum; 2016.

[3] UNESCO-Kedi. Educating for the 4th Industrial Revolution. In: United Nations Educational SaCO-KEDIU-K, editor. 2017.

[4] Klaus S. The Fourth Industrial Revolution. UK: Peguin Random House; 2017.

[5] Balliester T, Elsheikhi A. The future of work: A literature review. In: Office IL, editor. 2018.

[6] Singh S, Sarkar K, Bahl N. Fourth Industrial Revolution, Indian labour market and continuing engineering education. International Journal of Research in Engineering, IT and Social Sciences. 2018;8(3):6-12.

[7] Frey CB, Osborne MA. The future of employment: How susceptible are jobs to computerisation? Technological Forecasting and Social Change. 2017;114(C):254-80. https://doi.org/10.1016/j.techfore.2016.08.019

[8] Arntz M, Gregory T, Zierahn U. The risk of automation for jobs in OECD Countries: A comparative analysis. In: Publishing O, editor. Paris2016.

[9] McKinsey. A future that works: Automation, employment and productivity. New York: McKinsey \& Company; 2017.

[10] Deloitte. Agiletown: The relentless march of technology and London's response. London: Futures; 2014.

[11] World Bank. World development report : digital dividends. Wahington DC: The World Bank; 2016. https://doi.org/10.1596/978-1-4648-0671-1 ch4

[12] Agency of Strategic Initiatives. Atlas of Emerging Jobs. Moscow: Skolkovo; 2015.

[13] World Economic Forum. The global competitiveness report. Geneva: World Economic Forum; 2015. 
[14] World Economic Forum. Realizing human potential in the Fourth Industrial Revolution : An agenda for leaders to shape the future of education, gender and work. Geneva: World Economic Forum; 2017b.

[15] Restrepo P. Skill mismatch and structural unemployment. 2015.

[16] Solomon W. Polachek K, Pouliakas Giovanni, Russo, Konstantinos T. Skill mismatch in labor markets. Research in Labor Economics. 2017;45. https://doi.org/10.1108/s0147$\underline{9121201745}$

[17] McKinsey \& Company. Offline and falling behind: Barriers to Internet adoption. 2014.

[18] UKCES. UKCES Employer Skills Survey. London: UK Commission for Employment and Skills.; 2013.

[19] Hamzeh R, Zhong R, Xu XW. A survey study on industry 4.0 for New Zealand manufacturing. Procedia Manufacturing. 2018;26:49-57. https://doi.org/10.1016/j.promfg.2018.07.007

[20] Nooriah Y, Zakiyah J. Graduate employability and preparedness: A case study of University of Malaysia Perlis (UNIMAP), Malaysia GEOGRAFIA Online Malaysian Journal of Society and Space. 2015(11):129-43.

[21] Kaushal U. Empowering engineering students through employability skills. Higher Learning Research Communications. 2016;6(4). https://doi.org/10.18870/hlrc.v6i4.358

[22] Yuzainee MY. Pembangunan model pengukuran kemahiran kebolehgajian siswazah kejuruteraan di Malaysia [Doctoral dissertation]: Universiti Kebangsaan Malaysia; 2014.

[23] Boland A, Cherry MG, Dickson R. Doing a systematic review: A student's guide. London: Sage Publications Ltd; 2018.

[24] Merriam SB. Introduction to qualitative research. San Francisco: Jossey-Bass; 2002.

[25] Rosli A, Rasul MS, editors. Exploring the high income community education programme in Malaysia. 6th International Conference on Educational Reform (ICER 2013): ASEAN Education in the 21st Century; 2013.

[26] Mohamed Ashari ZH, Rasul MS, Azman N. Hubungan individu, persekitaran dan kebolehsesuaian terhadap pemilihan kerjaya pelajar Sistem Persijilan Kemahiran Malaysia (SKPM) : suatu analisis kandungan. Sains Humanika. 2014;2(1):135-44. https://doi.org/10.11113/sh.v10n3-2.1492

[27] Rahimi NHZ, Rasul MS, Mohamad Yasin R, editors. Ekosistem pembelajaran keusahawanan. International Conference on Education and Regional Development 2016 (ICERD 2016; 2016 October 31st \& November 1st; Bandung, Indonesia.

[28] Adam S, Rasul MS, Mohamad Yasin R. Industry involvement conceptual framework for collaboration of National Dual Training Systems (NDTS) in Malaysia. Sains Humanika. 2017;9(2):33-41. https://doi.org/10.11113/sh.v9n2.1003

[29] Hussain AB, Hussein RM, Dahr JM, Neamah MA. Existing trends in usability evaluation method (Uem) for the M-learning apps: a systematic review. ARPN Journal of Engineering and Applied Sciences. 2015;10.

[30] Kitchenham B. Guidelines for performing systematic literature reviews in software engineering. EBSE Technical Report. 2007.

[31] Tong LF, editor Identifying essential learning skills in students' engineering education, in learning for an unknown future. 26th HERDSA Annual Conference; 2003 6-9 July 2003; Christchurch, New Zealand: Higher Education Research and Development Society of Australasia, Inc.

[32] Low SM, editor Developing undergraduate students' multi-engineering skills through projects on embedded system. 7th International Conference on Information Technology Based Higher Education and Training; 2006 July 10-13; Ultimo, Australia: IEEE. https://doi.org/10.1109/ithet.2006.339805 
[33] Markes I. A review of literature on employability skill needs in engineering. European Journal of Engineering Education. 2006;31(6):637-50.

https://doi.org/10.1080/03043790600911704

[34] Kumar S, Hsiao JK. Engineers learn "soft skills the hard way": Planting a seed of leadership in engineering classes. Leadership Manage 2007;7(2):18-23. https://doi.org/10.1061/(asce)1532-6748(2007)7:1(18)

[35] Sharma G, Sharma P. Importance of soft skills development in 21st century curriculum. International Journal of Education \& Allied Sciences. 2010;2(2):39-44.

[36] Balaji KA, Somashekar PP. A comparative study of soft skills among engineers. Indian University Press Journal of Soft Skills. 2009;3(3/4):50-7.

[37] Woodward BS, Sendall P, Ceccucci W. Integrating soft skill competencies through project-based learning across the Information Systems curriculum. Information Systems Education Journal 2010;8(8).

[38] Mohd Zuhdi IA, Mohd Nizam AR, Ruhizan MY. Ketidaksepadanan kemahiran dan kolaborasi industri - Institusi PLTV di Malaysia: Satu cadangan penyelesaian. SkillsMalaysia Journal. 2017;3(1):17-22.

[39] Patacsil FF, Fernandez MM, Cenas PV. Exploring the importance of employability skills as perceived by OJT engineering students and industry partners. International Journal of Multidisciplinary Academic Research. 2017;5(2):23-35.

[40] NACE. Job Outlook 2018. National Association of Colleges and Employers (NACE); 2017.

[41] Nguyen ND, Yoshinari Y, Shigeji M. University education and employment in Japan. Quality Assurance in Education. 2005;13(2):202-18. https://doi.org/10.1108/09684880510607945

[42] Zaharim A, Yusoff YM, Omar MZ, Mohamed A, Muhamad N, editors. Engineering employability skills required by employers in Asia. 6th WSEAS International Conference on Engineering Education; 2009b July 22-24, 2009; Rodos Island, Greece. https://doi.org/10.1109/iceed.2009.5490607

[43] Zaharim A, Yusoff YM, Omar MZ, Mohamed A, Muhamad N. The comparison on priority engineering employability skills. International Journal of Engineering and Technology. 2010;7(2):61-74.

[44] Blom A, Saeki H. Employability and skill set of newly graduated engineers in India. India: The World Bank; 2011. https://doi.org/10.1037/e596532012-001

[45] Hanapi Z, Nordin MS. Unemployment among Malaysia graduates: graduates'attributes, lecturers' competency and quality of education. Procedia - Social and Behavioral Sciences. 2014;112:1056-63. https://doi.org/10.1016/j.sbspro.2014.01.1269

[46] Nordin MK. Project-based learning framework for non-technical skills: Universiti Teknologi Malaysia; 2014.

[47] Fathiyah MK, Hamid R, Mutalib AA, Rasul MS. Conceptual framework for the development of 4IR skills for engineering graduates. Global Journal of Engineering Education. 2019;21(1):54-61.

[48] World Economic Forum. The future of jobs report : Centre for the new economy and society. Geneva: World Economic Forum; 2018.

[49] Nair CS, Patil A, Mertova P. Re-engineering graduate skills - a case study. European Journal of Engineering Education. 2009;34(2):131-9. https://doi.org/10.1080/03043790902829281

[50] Wong R, Tsang A. Engineering Graduates Generic Skills: Issues and Solutions. 2009.

[51] Zaharim A, Yusoff YM, Omar MZ, Mohamed A, Muhamad N, editors. Employers' perceptions and expectation toward engineering graduates: a study case. 6th WSEAS Interna- 
tional Conference on Engineering Education; 2009a July 22-24, 2009; Rodos Island, Greece. https://doi.org/10.1109/iceed.2009.5490607

[52] Mustapha R, Husain MY, Mokhtar SB, Bakar EA, Safian MA. Kemahiran 'employabilty' dari perspektif pelajar kejuruteraan. Persidangan Kebangsaan Penyelidikan dan Inovasi dalam Pendidikan dan Latihan Teknik dan Vokasional (CIE-TVET 2011); 16-17 November 2011; Pulau Pinang2011.

[53] Hassan SNH, Zamberi MM, Khalil SN, Sanusi N, Wasbari F, Kamarolzaman AA. Company perception on the employability skills of industrial training students. Journal of Technical Education and Training. 2012;4(2):1-8.

[54] Mai RC. Developing soft skills in Malaysian polytechnics students : perspectives of employers and students. Asian Journal of Management Sciences and Education. 2012;1(2):4451.

[55] Creasey R. Improving students' employability. Engineering Education. 2013;8(1):16-30.

[56] Husain MY, Rasul MS, Mustapha R, Malik SA, Rauf RAA. Tahap kemahiran employability pelajar kejuruteraan dari perspektif majikan. Jurnal Teknologi (Social Scicences). 2013;62(1):31-9. https://doi.org/10.11113/jt.v62.1372

[57] Noorazman AS, Noor Hisham J, Wan Mohd Rashid WA, Harun H, Amiruddin MH, Keong APP. Tahap kemahiran insaniah dalam kalangan pelajar kejuruteraan tahun akhir di Politeknik Primer Malaysia. Seminar Antarabangsa Pertama Pendidikan Teknik dan Vokasional 2014 (TVEIS 2014)2014.

[58] Esa A, Selamat A, Padil S, Jamaludin J. Applications of soft skills in engineering programme at Polytechnic Malaysia. Procedia - Social and Behavioral Sciences. 2014;140:115-20. https://doi.org/10.1016/j.sbspro.2014.04.395

[59] Mohamad Idham MR, Yusof AM, Syazana WN, Jaafar WE, Talib AH. Factors influencing unemployment among graduates in Malaysia- An overview. Journal of Economics and Sustainable Development. 2014;5(22):168-73.

[60] Puad MHM. The role of employability skills training programs in the workforce of Malaysia: Purdue University; 2015.

[61] Ramadi E, Ramadi S, Nasr K. Engineering graduates' skill sets in the MENA region: a gap analysis of industry expectations and satisfaction. European Journal of Engineering Education. 2015;41(1):34-52. https://doi.org/10.1080/03043797.2015.1012707

[62] Ramlan R, Ngah S. Student perception on the importance of soft skills for education and employment. PEOPLE : International Journal of Social Sciences. 2015;1(1):696-708.

\section{$7 \quad$ Authors}

Mohd Kamaruzaman, F. is with the department of Centre of Engineering and Built Environment Education Research, Faculty of Engineering and Built Environment, Universiti Kebangsaan Malaysia, Selangor D.E., Malaysia. fathiyah@ukm.edu.my

Hamid, R, Mutalib, A.A. is with the Smart and Sustainable Township Research Centre, Faculty of Engineering and Built Environment, Universiti Kebangsaan Malaysia, Selangor D.E., Malaysia

Rasul, M.S. is with the STEM Enculturation Center, Faculty of Education, Universiti Kebangsaan Malaysia, Selangor D.E., Malaysia

Article submitted 2019-02-16. Resubmitted 2019-04-08. Final acceptance 2019-05-26. Final version published as submitted by the authors. 